\title{
Penerapan Supervisi Klinis Dalam Upaya Meningkatkan Kemampuan Guru Mengajar Tematik Kurikulum 2013 Di SDN No.65 Kota Timur Tahun Pelajaran 2018/2019
}

\author{
Sunartty Jusuf \\ SDN NO.65 Kota Timur \\ Sunartty.jusuf02@gmail.com
}

Received: 13 August 2021; Revised: 02 October 2021; Accepted: 14 December 2021

DOI: http://dx.doi.org/10.37905/aksara.8.1.237-248.2022

\begin{abstract}
Abstrak
Permasalahan dalam penelitian ini apakah supervisi klinis dapat meningkatkan Kemampuan Guru dalam mengajar tematik kurikulum 2013 di SDN No.65 Kota Timur? Adapun tujuan dari pelaksanaan penelitian ini adalah untuk meningkatan Kemampuan guru dalam mengajar tematik kurikulum 2013 melalui supervisi klinis di SDN No. 65 Kota Timur. Hasil analisis data menunjukan ada peningkatan hasil kemampuan Guru dalam mengajar tematik kurikulum 2013 dari siklus ke siklus. Hal tersebut ditunjukan oleh analisis kemampuan guru pada setiap siklus. Pada siklus I yaitu dari dari 16 orang guru yang disupervisi, diperoleh bahwa 11 orang atau $68.8 \%$ telah memiliki kemampuan mengajar tematik kurikulum 2013 berbasis saintifik dengan baik. Pada siklus II sudah mengalami peningkatan yakni dari 16 orang guru yang disupervisi, diperoleh bahwa 14 orang atau $87.5 \%$ telah memiliki kemampuan mengajar tematik kurikulum 2013 berbasis saintifik. Dengan demikian, hal ini sudah memenuhi indikator kinerja dalam penelitian ini yaitu apabila Kemampuan guru dalam mengajar tematik kurikulum 2013 mencapai prosentase $80 \%$, maka penelitian dianggap berhasil.
\end{abstract}

Kata Kunci: kemampuan guru, supervisi klinis

\section{PENDAHULUAN}

Secara umum kepala Sekolah mempunyai peran dan fungsi yang menjamin mutu satuan pendidikan. Peran kepala sekolah dalam jabatan strategis di dunia pendidikan adalah sebagai seorang educator, leader, manajer, administrator, climate maker, supervisor, entrepreneur, instructional leader, program facilitator, community facilitator, visionary, dan problem solver. Salah satu peran kepala sekolah tersebut adalah supervisor. Kepala sekolah sebagai supervisor akan sangat membantu guru dalam meningkatkan kemampuan mengajarnya dengan membantu mengobservasi, merefleksi, dan menganalisis tingkah laku mengajarnya itu. Meskipun supervisi itu sangat penting dalam upaya peningkatan kemampuan profesional guru, namun seringkali guru kurang menyukai supervisi tersebut.

Kita ketahui bersama bahwa pekerjaan menjaga, mengatur, mengawasi atau memberi bantuan disebut supervisi dan pemberi bantuan disebut supervisor. Terdapat beberapa alasan yang menjadi dasar pentingnya supervisi dalam praktek mengajar untuk guru, antara lain: (1) guru dapat berinteraksi dengan peserta didik, memberikan keteladanan, motivasi dan inspirasi untuk terus bersemangat belajar, berkarya dan berprestasi. (2) guru paling tidak harus memiliki tiga kemampuan dasar yaitu kemampuan personal, profesional dan sosial (Depdiknas, 2008)

Berdasarkan kajian tentang beberapa supervisi yang biasa dilakukan kepala sekolah, terdapat salah satu kegiatan yang memicu adrenalin guru dalam mengajar yaitu supervisi klinis. secara umum supervisi klinis diartikan sebagai bentuk bimbingan profesional yang diberikan kepada guru berdasarkan kebutuhannnya melalui siklus yang 
sistematis. Siklus sistematis ini meliputi: perencanaan, observasi yang cermat atas pelaksanaan dan pengkajian hasil observasi dengan segera dan obyektif tentang penampilan mengajarnya yang nyata (dalam Muhtar dan Iskandar,2009: 47). Supervisor diharapkan untuk mengajarkan berbagai ketrampilan kepada guru. Ketrampilan tersebut meliputi: Ketrampilan mengamati memahami (mempersepsi) proses pembelajaran secara analitik; Ketrampilan menganalisis proses pembelajaran secara rasional berdasarkan bukti-bukti pengamatan yang jelas dan tepat; Ketrampilan dalam pembaharuan kurikulum, pelaksanaan serta pencobaannya; dan Ketrampilan dalam mengajar.

Berdasarkan hasil observasi awal,diperoleh informasi melalui wawancara dengan salah seorang guru yakni terdapat beberapa keluhan guru tentang kegiatan supervise klinis berupa (1) Perencanaan supervisi klinis yang masih kurang terperinci (2) Pelaksanaan jadwal supervisi klinis yang belum teratur dan sering mengalami penundaan.(3) Minat guru dalam pelaksanaan supervisi klinis masih rendah, ini dibuktikan dengan keengganan guru dalam kegiatan supervisi klinis, berusaha menghindar dengan mengikuti kegiatan lain di luar sekolah. (4) Tindak lanjut kegiatan supervisi klinis yang belum intensif. Data pada observasi awal menunjukan bahwa dari 16 orang guru, yang sudah memiliki kemampuan mengajar tematik kurikulum 2013 namun masih perlu bimbingan berjumlah 9 orang atau 56,25\% sedangkan yang belum memiliki kemampuan mengajar tematik kurikulum 2013 sesuai PERMEN terbaru berjumlah 7 orang atau $43,75 \%$. Dengan demikian, hal ini membutuhkan strategi yang tepat untuk mengatasi permasalahan tersebut agar memberikan hasil sesuai dengan harapan peneliti sebagai kepala sekolah, pengawas, guru dan sekolah sebagai lembaga yang menfasilitasi penelitian ini.

Mencermati permasalahan tersebut di atas, maka seorang kepala sekolah diharapkan mampu membentuk seorang guru yang ideal dan berkinerja tinggi. Salah satu strategi yang bisa ditawarkan dalam penelitian ini adalah supervisi klinis. Hal ini berdasar pada Keunggulan supervisi klinis dapat digunakan untuk meningkatkan kemampuan guru dalam mengajar karena dengan semakin baiknya guru mengajar maka siswa juga semakin mudah dalam menerima pelajaran. Peningkatan cara mengajar mengakibatkan siswa semakin senang dengan pelajaran yang diikutinya. Apabila pola supervisi klinis dapat terlaksana dengan baik sesuai dengan amanat Peraturan Pemerintah No. 19 Tahun 2005, diharapkan akan meningkatkan mutu pendidikan Nasional pada umumnya.

Secara psikologi, belajar merupakan suatu proses perubahan dalam memenuhi kebutuhan hidupnya. Definisi belajar telah banyak dikemukakan oleh para ahli pendidikan. Namun pada dasarnya belajar merupakan suatu proses mental yang dinyatakan dalam berbagai bentuk prilaku. Slameto (1991:78) mengatakan bahwa belajar merupakan suatu proses usaha yang dilakukan individu untuk memperoleh suatu perubahan tingkah laku yang baru secara keseluruhan, sebagai hasil pengalaman individu itu sendiri dalam interaksi dengan lingkungannya. Sejalan dengan itu, Hamalik (2001:27) mengatakan bahwa Belajar adalah modifikasi atau memperteguh kelakuan melalui pengalaman. Suryabrata (1991:45) bahwa belajar adalah suatu proses yang menghasilkan perubahan perilaku yang dilakukan dengan sengaja untuk memperoleh pengetahuan, kecakapan, dan pengalaman baru kearah yang lebih baik. 
Belajar menurut Bandura (dalam Gunarsa, 1990:184) adalah suatu proses sosialisasi dengan memperhatikan orang lain melakukan pekerjaan yang selanjutnya lebih dipertegas oleh Sudrajat (2005:35) yaitu belajar sebagai suatu proses dimana suatu organisme berubah perilakunya sebagai akibat pengalaman. Alloway\&Gathercole (2009:58) dalam sebuah situs menjelaskan bahwa belajar berupa anak harus menggali pengertian yang digambarkan melalui hubungan antar tiap kata.

Witherington (dalam Usman dan Setiawati, 2001:5) mengemukakan bahwa belajar adalah sesuatu perubahan di dalam kepribadian yang menyarankan diri sebagai suatu pola baru dari reaksi. yang berupa kecakapan, sikap, kebiasaan atau suatu pengertian". Winataputra, dkk (1993:148) memandang bahwa "belajar merupakan suatu perubahan tingkah laku". Belajar merupakan suatu perubahan tingkah laku yang terjadi melalui latihan atau pengalaman. Untuk dapat disebut belajar maka perubahan itu harus relatif menetap. Tingkah laku yang mengalami perubahan karena menyangkut berbagai aspek kepribadian baik fisik maupun psikis, seperti perubahan dan pengertian, pemecahan suatu masalah atau berfikir, keterampilan, kecakapan, kebiasaan atau sifat. Berdasarkan definisi tersebut, maka belajar merupakan suatu proses, suatu kegiatan dan bukan suatu hasil atau tujuan. Belajar bukan saja hanya mengingat akan tetapi dalam lebih arti luas dari itu yakni memahami. Hasil belajar bukan suatu penguasaan hasil latihan melainkan pengubahan tingkah laku. Di samping itu pula, kita dapat menyimpulkan bahwa belajar bukan hanya mentransper ilmu pengetahuan dari guru kepada siswa dalam bentuk hafalan saja, melainkan seluruh potensi pada diri siswa harus dikembangkan, yaitu afektifnya, juga psikomotornya, sehingga diharapkan melalui belajar ini anak/siswa akan menjadi manusia seutuhnya sesuai dengan harapan tujuan pendidikan nasional.

Pembelajaran merupakan suatu proses yang paling inti dalam dunia pendidikan dengan guru sebagai ujung tombak keberhasilan disamping stakeholder lainnya. Terkait dengan pembelajaran, Kartadinata dan Dantes (1997: 44) mengemukakan bahwa proses pembelajaran adalah proses aktif dan dinamis, menghendaki keterlibatan guru dan siswa, merupakan ilmu yang memungkinkan terjadinya proses belajar pada siswa, sebagai proses inkuiri reflektif dan menempatkan perkembangan sebagai tujuan. Sukmadinta dalam sebuah situs dijelaskan bahwa pembelajaran adalah suatu usaha yang sengaja melibatkan dan menggunakan pengetahuan profesional yang dimiliki guru untuk mencapai tujuan kurikulum. Jadi pembelajaran adalah suatu aktivitas yang dengan sengaja untuk memodifikasi berbagai kondisi yang diarahkan untuk tercapainya suatu tujuan yaitu tercapainya tujuan kurikulum. Pembelajaran atau pengajaran pada dasarnya merupakan kegiatan guru/dosen menciptakan situasi agar siswa/mahasiswa belajar. Tujuan utama dari pembelajaran ini adalah agar siswa/mahasiswa belajar

Uzer (2000: 4) mengemukakan bahwa "peristiwa pembelajaran banyak berakar dari berbagai pandangan dan konsep. Oleh karena itu perwujudan proses pembelajaran dapat terjadi dalam berbagai model”. Lebih lanjut, Joyce Et. Al (Samatowa, 2006 :74) menambahkan tentang konsep pembelajaran. Menurut beliau pembelajaran perolehan konsep yang hendaknya memberikan kesempatan untuk terjadi transaksi aktif antara individu dengan data, dan proses berurutan yang bertujuan untuk menganalisis strategi berfikir. Gagne dan Briggs (1979:3) dalam sebuah situs mengartikan instruction atau pembelajaran ini adalah suatu sistem yang bertujuan untuk membantu proses belajar siswa, yang berisi serangkaian peristiwa yang dirancang, disusun sedemikian rupa untuk 
mempengaruhi dan mendukung terjadinya proses belajar siswa yang bersifat internal. Sepintas pengertian mengajar hampir sama dengan pembelajaran namun pada dasarnya berbeda. Dalam pembelajaran kondisi atau situasi yang memungkinkan terjadinya proses belajar harus dirancang dan dipertimbangkan terlebih dahulu oleh perancang atau guru. Sementara itu dalam kehidupan sehari-hari di sekolah, istilah pembelajaran atau proses pembelajaran Ilmu Pengetahuan Alam sama dengan proses belajar mengajar dimana di dalamnya ada interaksi guru dan siswa dan antara sesama siswa untuk mencapai suatu tujuan yaitu terjadinya perubahan sikap dan tingkah laku siswa.

Dari beberapa pengertian para ahli tersebut dapat disimpulkan bahwa pembelajaran adalah proses kegiatan belajar mengajar yang berlangsung di suatu keadaan dengan siswa dan guru adalah tokoh utamanya.

Kemampuan menurut Kunandar adalah suatu yang dimiliki oleh seseorang untuk melakukan tugas dan pekerjaan yang dibebankan kepadanya (Kunandar, 2008:52) Menurut Broker dan Stone dalam Cece Wijaya (1991:7-8) memberikan pengertian kemampuan guru adalah sebagai gambaran hakikat kualitatif dari perilaku guru atau tenaga kependidikan yang tampak sangat berarti.

Terkait dengan hal tersebut, Suprayati dalam Kunandar (2005;57) mengemukakan bahwa kemampuan mengajar adalah sejumlah kompetensi guru yang menampilkan kinerjanya secara profesional. Kemampuan ini menunjukkan bagaimana guru memperlihatkan perilakunya selama interaksi dalam pembelajaran, meliputi: 1) Keterampilan membuka pelajaran, yaitu kegiatan guru untuk menciptakan suasana yang menjadikan siswa siap mental sekaligus menimbulkan perhatian siswa yang terpusat pada hal-hal yang akan dipelajari. 2) Keterampilan menutup pelajaran, yaitu kegiatan guru untuk mengakhiri proses pembelajaran. 3) Keterampilan menjelaskan, yaitu usaha penyajian materi pelajaran yang diorganisasikan secara sistematis. 4) Keterampilan mengelola kelas, yaitu kegiatan guru untuk menciptakan siklus belajar yang kondusif. 5) Keterampilan bertanya, adalah usaha guru untuk mengoptimalkan kemampuan menjelaskan melalui pemberian pertanyaan kepada siswa. 6) Keterampilan memberi penguatan, yaitu suatu respons positif yang diberikan guru kepada siswa yang melakukan perbuatan baik atau kurang baik. 7) Keterampilan memberi variasi, yaitu usaha guru untuk menghilangkan kebosanan siswa dalam menerima pelajaran melalui variasi gaya guru mengajar dan komunikasi nonverbal (suara, mimik, kontak mata dan semangat).

Adams dan Dickey (Hamalik,2004:48-49) mengatakan bahwa ada 13 peran guru di dalam kelas, antara lain: 1) Guru sebagai pengajar, yaitu menyampaikan ilmu pengetahuan, perlu memiliki keterampilan memberikan informasi kepada kelas. 2) Guru sebagai pemimpin kelas, perlu memiliki keterampilan cara memimpin kelompokkelompok murid. 3) Guru sebagai pembimbing, perlu memiliki keterampilan cara mengarahkan dan mendorong kegiatan belajar siswa. Guru sebagai pengantar lingkungan, perlu memiliki keterampilan mempersiapkan dan menyediakan alat dan bahan pelajaran. 5) Guru sebagai partisipan, perlu memiliki keterampilan cara memberikan saran, mengarahkan pemikiran kelas dan memberikan penjelasan. 6) Guru sebagai ekspeditur, perlu memiliki keterampilan menyelidiki sumber-sumber masyarakat yang akan digunakan. 7) Guru sebagai perencana, perlu memiliki keterampilan cara memilih dan meramu bahan pelajaran, secara profesional. 8) Guru sebagai supervisor, perlu memiliki keterampilan mengawasi kegiatan anak dan 
keterlibatan kelas. 9) Guru sebagai motivator, perlu memiliki keterampilan mendorong motivasi belajar kelas. 10) Guru sebagai penanya, perlu memiliki keterampilan cara bertanya yang merangsang kelas berfikir dan cara memcahkan masalah. 11) Guru sebagai pengajar, perlu memiliki keterampilan cara memberikan pengarahan terhadap anak-anak yang berprestasi. 12) Guru sebagai evaluator, perlu memiliki keterampilan cara menilai anak-anak secara objektf, kontiniu dan komprehensif. 13) Guru sebagai konselor, perlu memilki keterampilan cara membantu anak-anak yang mengalami kesulitan.

Berdasarkan definisi tersebut maka dapat diambil kesimpulan bahwa kemampuan mengajar guru adalah potensi atau kesanggupan yang dikuasai guru untuk melakukan suatu aktifitas atau kegiatan.

Penerapan kurikulum 2013 diimplementasikan adanya penambahan jam pelajaran, hal tersebut sebagai akibat dari adanya perubahan proses pembelajaran yang semula dari siswa diberi tahu menjadi siswa yang mencari tahu. Selain itu, akan merubah pula proses penialaiayang semula berbasis output menjadi berbasis proses dan output. Orientasi kurikulum 2013 adalah terjadinya peningkatan dan keseimbangan antara kompetensi sikap, keterampilan dan pengetahuan. Hal itu sejalan dengan amanat UU no.20 tahun 2003 sebagai mana tersurat dalam penjelasan pasal 35: "kompetensi lulusan merupakan kualifikasi kemampuan lulusan yang mencakup sikap, pengetahuan, dan keterampilan sesuai dengan standar yang telah disepakati”. Hal ini sejalan pula dengan pengembangan kurikulum berbasis kompetensi yang telah dirintis pada tahun 2004 dengan mencangkup kompetensi sikap, pengetahuan, dan keterampilan secara terpadu (Kurniasih dan Sani, 2014:8).

Yani (2014:92) memberikan argument bahwa Kurikulum 2013 merupakan pengembangan dari kurikulum 2006 namun lebih menekankan pada pemberian kesempatan peserta didik untuk mengembangkan potensi dirinya dalam mengembangkan kecerdasan sikap, pengetahuan dan keterampilannya. Struktur kurikulum 2013 relatif lebih ramping tetapi menambah jumlah jam pelajaran. Pendapat ini didukung oleh Kurniasih. Dan Sani (2014:7) yang menyatakan bahwa kurikulum 2013 dinyatakan sebagai serentetan rangkaian penyempurnaan terhadap kurikulum yang telah dirintis tahun 2004 yang berbasis kompetensi lalu diteruskan dengan kurikulum 2006 (KTSP).

Berdasarkan pendapat para ahli tersebut, maka dapat disimpulkan bahwa kurikulum 2013 merupakan rancangan yang memuat pembelajaran secara holistic pada tiga aspe yaitu sikap, pengetahuan dan keterampilan untuk konten pendidikan yang harus dimiliki oleh seluruh peserta didik setelah menyelesaikan pendidikannya di satu satuan atau jenjang pendidikan.

Definisi Supervisi secara umum dijelaskan oleh Kimball Wiles (Tim Pengembang, 2010:25) sebagai berikut: "Supervision is assistance in the devolepment of a better teaching learning situation". Supervisi adalah bantuan dalam pengembangan situasi pembelajaran yang lebih baik. Rumusan ini mengisyaratkan bahwa layanan supervisi meliputi keseluruhan situasi belajar mengajar (goal, material, technique, method, teacher, student, an envirovment). Situasi belajar inilah yang seharusnya diperbaiki dan ditingkatkan melalui layanan kegiatan supervisi. Dengan demikian layanan supervisi tersebut mencakup seluruh aspek dari penyelenggaraan pendidikan dan pengajaran. 
Ainamulyana (2015:2) mengemukakan bahwa Supervisi klinis adalah supervisi yang dilakukan berdasarkan adanya keluhan atau masalah dari guru yang disampaikan kepada supervisor. Supervisi klinis adalah bentuk supervisi yang difokuskan pada peningkatan mengajar dengan melalui siklus yan sistematik, dalam perencanaan, pengamatan serta analisis yang intensif dan cermat tentang penampilan mengajar yang nyata, serta bertujuan mengadakan perubahan dengan cara yang rasional. Supervisi klinis adalah pembinaan kinerja guru dalam mengelola proses pembelajaran (Sullivan \& Glanz, 2005 dalam Ainamulyana, 2015:4).

Supervisi klinis sebagai bagian dari model supervisi menurut Willem adalah bentuk supervisi yang difokuskan pada peningkatan mengajar dengan melalui siklus yang sistematik, dalam perencanaan, pengamatan serta analisis yang intensif dan cermat tentang penampilan mengajar yang nyata, serta bertujuan mengadakan perubahan dengan cara yang rasional (Sahertian, 2000:36). Sergiovanni dalam Madyo Ekosusilo, menyatakan bahwa pembinaan guru dengan pendekatan klinik adalah suatu pertemuan tatap muka antara pembina dengan guru, membahas tentang hal mengajar di dalam kelas guna perbaikan pengajaran dan pengembangan profesi (Ekosusilo, 2003; 25).

Cogan, ada delapan kegiatan dalam supervisi klinis yang dinamainya dengan siklus atau proses supervisi klinis. Delapan tahap tersebut mencakup tahap membangun dan memantapkan hubungan guru dengan supervisor, tahap perencanaan bersama guru, tahap perencanaan strategi observasi, tahap observasi pengajaran, tahap analisis proses belajar mengajar, tahap perencanaan strategi pertemuan, tahap pertemuan, dan tahap penjajakan rencana pertemuan berikutnya. Menurut Mosher dan Purpel, ada tiga aktivitas dalam proses supervisi klinis, yaitu tahap perencanaan, tahap observasi, dan tahap evaluasi dan analisis. Sedangkan menurut Oliva, ada tiga aktivitas esensial dalam proses supervisi klinis, yaitu kontak dan komunikasi dengan guru untuk merencanakan observasi kelas, observasi kelas, dan tindak lanjut observasi kelas (Arif, 2008:171)

Pidarta (Arif,2008:172) mengemukakan bahwa secara lebih rinci dari tahap supervise klinis yaitu: a. Proses pertemuan awal atau perencanaan Langkah dalam pertemuan awal atau perencanaan ini meliputi kegiatan: 1). Menciptakan hubungan yang baik dengan cara menjelaskan makna supervisi klinis sehingga partisipasi guru meningkat, 2). Menemukan aspek-aspek perilaku apa dalam proses belajar mengajar yang perlu diperbaiki, 3). Membuat prioritas aspek-aspek perilaku yang akan diperbaiki, 4). Membuat hipotesis sebagai cara atau bentuk perbaikan pada subtopik bahan pelajaran tertentu. Pertemuan awal dimaksudkan untuk mengembangkan bersama antara supervisor dengan guru tentang kerangka kerja pengamatan kelas yang akan dilakukan. Hasil akhir pertemuan ini adalah kesepakatan (contract) kerja antara supervisor dengan guru. Pertemuan awal tidak membutuhkan waktu yang lama, supervisor bisa menggunakan waktu 20 sampai 30 menit, kecuali jika guru mempunyai permasalahan khusus yang membutuhkan diskusi panjang. Pertemuan ini sebaiknya dilaksanakan di satu ruang yang netral, misalnya kafetaria, atau bisa juga di kelas. Pertemuan di ruang supervisor atau kepala sekolah kemungkinan akan membuat guru menjadi tidak bebas. Secara teknis, ada beberapa kegiatan yang harus dilaksanakan dalam pertemuan awal ini, yaitu; menciptakan suasana yang akrab dan terbuka, mengidentifikasi aspek-aspek yang akan dikembangkan guru dalam kegiatan pembelajaran, menerjemahkan perhatian guru ke dalam tingkah laku yang bisa diamati, mengidentifikasi prosedur untuk memperbaiki pembelajaran guru, membantu guru memperbaiki tujuannya sendiri, 
menetapkan waktu pengamatan pembelajaran di kelas, menyeleksi instrument pengamatan pembelajaran di kelas, dan memperjelas konteks pembelajaran dengan melihat data yang akan direkam. b. Proses melaksanakan pengamatan Proses melaksanakan pengamatan ada dua kegiatan yaitu guru mengajar dengan tekanan khusus pada aspek perilaku yang diperbaiki, dan supervisor mengobservasi. Proses melaksanakan pengamatan secara cermat, sistematis, dan objektif merupakan proses kedua dalam proses supervisi klinis. Perhatian observasi ini ditujukan pada guru dalam bertindak dan kegiatan-kegiatan kelas sebagai hasil tindakan guru.

\section{METODE PENELITIAN}

Penelitian ini dilaksanakan di SDN No. 65 Kota Timur Kota Gorontalo diawali dengan observasi data awal kemudian dilanjutkan dengan siklus I selama dua kali pemberian tindakan, dengan pengambilan data dilakukan pada pertemuan kedua. Penelitian ini dilaksanakan selama 3 bulan yaitu Januari-Maret 2019. Penelitian ini dilaksanakan di SDN No. 65 Kota Timur Kota Gorontalo dengan jumlah guru sebagai subyek adalah 16 orang dengan karakteristik yang berbeda.

Jenis Penelitian yang digunakan adalah Penelitian tindakan sekolah (school action research) sebagai suatu bentuk penelitian yang bersifat reflektif dengan melakukan tindakan-tindakan tertentu agar dapat memperbaiki dan atau meningkatkan praktek-praktek pembelajaran guru di kelas secara lebih profesional.

Adapun variabel yang menjadi sasaran penelitian tindakan sekolah ini guna menjawab permasalahan penelitian adalah sebagai berikut:

a. Variabel Input berupa Kemampuan guru dalam mengajar tematik kurikulum 2013 meliputi; (1) Pembuatan Rencana Pelaksanaan Pembelajaran, (2)

Pelaksanaan pembelajaran, (3) Evaluasi Pembelajaran. (4) Prota dan Prosem,

b. Variabel proses berupa penerapan supervisi klinis meliputi; (1) perencanaan, (2)

Pelaksanaan, (3) Pengamatan, (4) Evaluasi

c. Variabel Output berupa peningkatan Kemampuan guru dalam mengajar tematik kurikulum 2013.

Tasjid (2014:67) menjelaskan bahwa Setiap siklus atau prosedur langkahlangkah yang akan dilakukan dalam penelitian ini dilaksanakan terdiri dari empat komponen kegiatan pokok, yaitu (a) perencanaan (planning), (b) pelaksanaan tindakan (action) (c) refleksi (reflection), yang pada pelaksanaannya keempat komponen pokok itu berlangsung secara terus menerus dengan diselipkan modifikasi pada komponen perencanaan berupa perbaikan perencanaan dan tidakan.

Secara skematis prosedur Penelitian Tindakan Sekolah (PTS) disajikan pada gambar berikut:

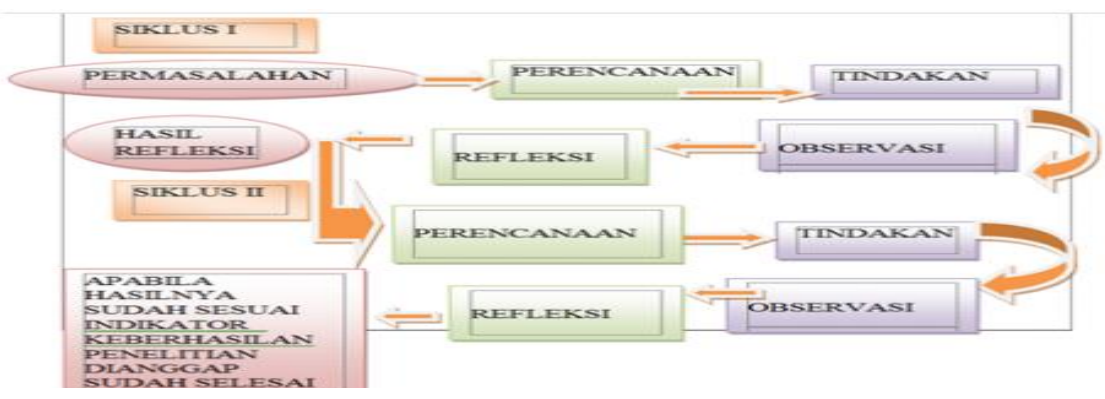

Gambar 3.1 Skema Penelitian Tindakan Sekolah 
Untuk mengumpulkan data dalam penelitian ini maka peneliti menggunakan beberapa teknik pengumpulan data sebagai berikut; (1) Observasi dan (2) Wawancara.

Analisa data yang peneliti gunakan adalah analisis diskriptif komparatif menghitung peningkatannya minimal 10\% dengan membandingkan kondisi awal, hasil siklus I dan hasil siklus II. Analisa nilai yang digunakan sebagai berikut:

1) Baik Sekali $=91-100$

2) Baik $=76-90$

3) Cukup $=61-75$

4) Kurang $=51-60$

5) Kurang Sekali $=<50$

\section{HASIL PENELITIAN DAN PEMBAHASAN \\ Gambaran Umum Lokasi Penelitian}

Seperti yang telah dijelaskan pada bab sebelumnya bahwa yang menjadi lokasi penelitian adalah SDN No. 65 Kota Timur yang terletak di Kelurahan Tamalate Kecamatan Kota Timur. Sekolah ini memiliki sarana dan prasarana yang cukup dan memenuhi syarat kelengkapan 8 Standar Nasional Pendidikan (SNP).

\section{Hasil Penelitian}

Hasil observasi awal menunjukan bahwa bahwa dari 16 orang guru, yang sudah memiliki kemampuan mengajar tematik kurikulum 2013 namun masih perlu bimbingan berjumlah 9 orang atau 56,25\% sedangkan yang belum memiliki kemampuan mengajar tematik kurikulum 2013 sesuai PERMEN terbaru berjumlah 7 orang atau 43,75\%.

\section{Siklus I}

Hasil tindakan pada siklus I dapat dilihat pada tabel 4.2 di bawah ini.

Tabel 4.2 Hasil Tindakan Siklus 1

\begin{tabular}{|l|c|c|c|c|}
\hline No & $\begin{array}{c}\text { Jumlah Guru } \\
\text { (Orang) }\end{array}$ & Nilai & Frekuensi & $\begin{array}{c}\text { Prosentase } \\
(\boldsymbol{\%})\end{array}$ \\
\hline 1 & 6 & 91 & 546 & 37.5 \\
\hline 2 & 5 & 80 & 400 & 31.3 \\
\hline 3 & 3 & 65 & 195 & 18.7 \\
\hline 4 & 2 & 60 & 120 & 12.5 \\
\hline Total & $\mathbf{1 6}$ & $\mathbf{2 9 6}$ & $\mathbf{1 2 6 1}$ & $\mathbf{1 0 0}$ \\
\hline
\end{tabular}

Berdasarkan tabel tersebut, dapat dijelaskan bahwa: (1) Dari 16 orang guru yang disupervisi, diperoleh bahwa 11 orang atau $68.8 \%$ telah memiliki kemampuan mengajar tematik kurikulum 2013 berbasis saintifik dengan baik (2) Dari 16 orang guru yang disupervisi, diperoleh bahwa 5 orang atau $31.2 \%$ belum memiliki kemampuan mengajar tematik kurikulum 2013 berbasis saintifik (3) Daya serap masih mencapai 78.8\%

\section{Refleksi}

Sesuai dengan hasil refleksi, ditemukan beberapa kelemahan pada pelaksanaan kegiatan adalah: (a) tidak tepatnya penggunaan kata-kata operasional dalam merinci komponen indikator pencapaian. (b) dalam kegiatan pembelajaran pendahuluan: sedikit yang mencamtumkan kegiatan apersepsi dan motivating (c) penggunaan metode terlalu didominasi metode ceramah, (d) guru kesulitan menentukan kegiatan pembelajaran yang dilakukan secara sistematis, (e) guru kesulitan menentukan metode pembelajaran yang disesuaikan dengan situasi dan kondisi peserta didik, serta karakteristik dari setiap 
indikator dan kompetensi yang hendak dicapai. (f) alokasi waktu yang tidak sesuai dengan pembelajaran.

\section{Deskripsi Siklus II}

Hasil yang diperoleh dapat dilihat pada tabel 4.3 berikut ini

Tabel 4.3 Hasil Tindakan Siklus 2

\begin{tabular}{|l|c|c|c|c|}
\hline No & $\begin{array}{c}\text { Jumlah Guru } \\
\text { (Orang) }\end{array}$ & Nilai & Frekuensi & $\begin{array}{c}\text { Prosentase } \\
(\mathbf{\%})\end{array}$ \\
\hline 1 & 8 & 98 & 784 & 50 \\
\hline 2 & 6 & 90 & 540 & 37.5 \\
\hline 3 & 2 & 65 & 130 & 12.5 \\
\hline Total & $\mathbf{1 6}$ & $\mathbf{2 5 3}$ & $\mathbf{1 4 5 4}$ & $\mathbf{1 0 0}$ \\
\hline
\end{tabular}

Berdasarkan tabel tersebut, dapat dijelaskan bahwa: (1) Dari 16 orang guru yang disupervisi, diperoleh bahwa 14 orang atau $87.5 \%$ telah memiliki kemampuan mengajar tematik kurikulum 2013 berbasis saintifik (2) Dari 16 orang guru yang disupervisi, diperoleh bahwa 2 orang atau $12.5 \%$ belum memiliki kemampuan mengajar tematik kurikulum 2013 berbasis saintifik (3) Daya serap masih mencapai 90.88\%

\section{Pembahasan}

Berdasarkan hasil penelitian, jelaslah bahwa pendekatan supervise klinis sangat tepat digunakan untuk meningkatkan Kemampuan guru dalam mengajar tematik kurikulum 2013.

Berdasarkan gambaran di atas, sangatlah jelas Kemampuan guru dalam mengajar tematik kurikulum 2013 meningkat pada siklus I sampai dengan pelaksanaan tindakan Siklus II, dengan demikian terbukti setelah melalui penelitian tindakan sekolah ini, Kemampuan guru dalam mengajar tematik kurikulum 2013 akan meningkat melalui penerapan supervise klinis. Dengan demikian hipotesis tindakan dalam penelitian ini dapat Diterima.

\section{KESIMPULAN}

Berdasarkan pembahasan pada bab sebelumnya, maka dapat disimpulkan bahwa: (1) Supervisi Klinis dapat meningkatkan kemampuan guru dalam mengajar tematik kurikulum 2013 di SDN No. 65 Kota Timur (2) Supervisi klinis dapat meningkatkan kinerja guru dalam melaksanakan pembelajaran dengan langkah-langkah sebagai berikut. (a) Supervisor yang mengamati guru mengajar tidak sebagai penilai tetapi sebagai rekan bekerja yang siap membantu guru tersebut, (b) Selama pelaksanaan supervisi di kelas guru tidak menganggap supervisor sebagai penilai karena sebelum pelaksanaan supervisi guru dan supervisor telah berdiskusi permasalahan-permasalahan yang ada dalam pembelajaran tersebut, (c) Supervisor mencatat semua peristiwa yang terjadi di dalam pembelajaran baik yang positif maupun yang negatif, (d) Jika ada guru yang pembelajarannya kurang jelas tujuan, penyajian, umpan balik, supervisor memberikan contoh bagaimana menjelaskan tujuan, menyajikan, memberi umpan balik kepada guru tersebut, (e) Setelah guru diberi contoh pembelajaran modern, Supervisor setiap dua atau tiga minggu mengunjungi atau mengikuti guru tersebut dalam proses pembelajaran. 


\section{SARAN}

Berdasarkan simpulan tersebut, maka dapat disarankan beberapa hal yaitu; (1) Bagi Kepala Sekolah: Memprogramkan adanya pelaksanaan supervisi klinis terhadap guru-guru yang dilakukan oleh kepala sekolah secara rutin setiap tahun, agar dapat meningkatkan kemapuan guru dalam mengefektifkan proses belajar mengajar di kelas. (2) Bagi Guru: hendaknya mengoptimalkan perannya sebagagi perencana, pengorganisir dan penilai pembelajaran yang handal. (3) Bagi Sekolah: Kegiatan supervis klinis sebaiknya dilaksanakan sebagai program sekolah utama yang memiliki indikator jelas sehingga terukur (5) Bagi Dinas Pendidikan Kota Gorontalo: Hasil penelitian ini dapat dijadikan masukan dalam upaya pembinaan terhadap pengawas sekolah untuk meningkatkan kinerja mereka khususnya dalam hal menerapkan supervise klinis agar pembinaan yang diberikan pada guru lebih dirasakan manfaatnya.

\section{DAFTAR PUSTAKA}

Coni Semiawan. 1999. Perkembangan Belajar Peserta Didik. Depdikbud Dikti. Proyek pendidikan guru sekolah dasar.

Dantes dan Kartadinata. 1996/1997. Landasan-Landasan Pendidikan Di Sekolah Dasar. Depdikbud. Dirjen Pendidikan Tinggi. Bagian Proyek Pengembangan PGSD.

Hamalik, 2001. Proses Belajar Mengajar. Jakarta : Rineka Cipta

Harjosumarto, Sarbini. 2003. Karakteristik siswa, teori belajar dan teori pembelajaran. Jakarta: DPLP Dirjen pendidikan dasar dan menegah.

Hamalik Oemar. 2004. Pendidikan Guru Berdasarkan Pendidikan Kompetensi, Jakarta: Bumi Aksara.

Hoetomo.2005. Kamus Lengkap Bahasa Indonesia. Surabaya: PT. Mitra Pelajar

Kunandar. 2008. Guru Profesional Implementasi KTSP dan Sukses dalam Sertifikasi Guru. Jakarta: Grafindo Persada

Majid Abdul. 2005. Perencanaan Pembelajaran. Bandung: PT Remaja Rosdakarya

Masaong Kadim Abd\&Tilome A Arfan. 2011. Kepemimpinan Berbasis Multiple Intelligence. Bandung: Alfabeta

Munandar. 2009. Kapita Selekta Pendidikan. Jakarta: AV Publisher

Mulyasa.2009. Standar Kompetensi dan Sertifikasi Guru. Bandung: PT Remaja Rosdakarta.

Msuratman. 2012. Supervisi klinis oleh kepala sekolah. https://msuratman.wordpress.com/2019/03/10/supervisi-akademik-olehkepala-sekolah/

Nasution, Noehi dan Budiastra, ketut. 2000. pendidikan ILMU PENGETAHUAN ALAM di Sekolah Dasar. Pusat Penerbitan Universitas Terbuka: Jakarta.

Samatowa, Usman. 2006. Bagaimana membelajarkan ILMU PENGETAHUAN ALAM di Sekolah Dasar. PT. Pustaka Indonesia Press: Jakarta.

Sahertian Piet. A. 2000. Konsep Dasar dan Teknik Supervisi Pendidikan (dalam Rangka Pengembangan Sumber Daya Manusia)

Saiful Arif.2008. Implementasi Supervisi Klinis. Jurnal Tadris3, no. 2.

Samatowa Usman, M.Pd Drs. 2009. Daya Pikir dan Daya Cipta. Gorontalo: @ ndragogika press.

Slameto. 1991. Belajar dan faktor. Rineka Cipta: Jakarta. 
Sujiono Bambang Dkk. 2005. Metode Pengembangan Fisik. Jakarta: Universitas Terbuka

Suryasubrata. 1991. Cara Mengajar dengan Hasil Yang Baik. Yogyakarta: Kanisius

Sumantri, Mulyani dan Permana, Johar. 1998/1999. Strategi belajar mengajar. Depdikbud, Dirjen Pendidikan tinggi Proyek PGSD

Tasjid.2014. Jurnal Penelitian Tindakan Sekolah dan Kepengawasan Vol. 1, No. 1Supervisi Klinis Dalam Peningkatan Kompetensi Guru Menyusun Rencana Pelaksanaan Pembelajaran.ISSN 2355-9683:Brebes

Tim Pengembang. 2010. Laporan PTS upaya peningkatan kompetensi gurudalam menyusun silabus dan rpp melaluisupervisi klinis yang berkelanjutandi SMAN 1 Tenjo Kab. Bogor. SMAN 1 Tenjo: Bogor

Uzer, Usman dan Setiawati. 2001. Upaya Optimalisasi Kegiatan Belajar Mengajar. Remaja Rosda karya: Bandung.

Cece Wijaya.1991. Kemampuan Dasar Guru dalam Proses Belajar Mengajar. Bandung: Remaja Rosdakarya.

Yani Ahmad. 2014. Mindset Kurikulum 2013. Bandung:Alfabeta.

https://ainamulyana.blogspot.com/2019/05/pengertian-dan-tujuan-supervisi-klinis.html 
AKSARA: Jurnal Ilmu Pendidikan Nonformal

P-ISSN 2407-8018 E-ISSN 2721-7310 DOI prefix 10.37905

Volume 08, (1), January 2022

http://ejurnal.pps.ung.ac.id/index.php/Aksara 